\title{
ACTIVATION OF GUANYLATE CYCLASE AS SECONDARY REACTION FOLLOWING INCREASE IN INTRACELLULAR Ca ION CONCENTRATIONS
}

\author{
Issei TAKAYANAGI, Tetsuhiro HISAYAMA and Takeshi KOTSUGAI \\ Department of Chemical Pharmacology, Toho University School of Pharmaceutical Sciences. \\ Miyama, Funabashi, Chiba 274, Japan
}

Accepted May 17, 1981

It was reported by Schultz et al. (1) that remova! of $\mathrm{Ca}^{2^{+}}$from bath fluid failed to increase the tissue level of cyclic GMP produced by smooth muscle stimulants. On the other hand. Wallach and Pastan (2) reported that guanylate cyclase activity in cultured fibroblasts was stimulated by physiological concentrations of $\mathrm{Ca}^{\text {?+ }}$. These studies suggest the possibility that increase in the tissue level of cyclic GMP induced by smooth muscle stimulants does not initiate smooth muscle contraction but due to activation of guanylate cyclase following the increase of the intracellular $\mathrm{Ca}^{2+}$ concentrations. In the present study, we attempted to assess whether or not interactions of the smooth muscle stimulants with their receptors increase cyclic GMP formation, after increasing intracellular $\mathrm{Ca}^{2+}$ concentrations to induce contraction of smooth muscle.

Takayanagi et al. (3) found that, though a cholinergic stimulant and serotonin increased the tissue level of cyclic GMP in the guinea pig taenia caecum, the tissue level of cyclic GMP in the longitudinal muscle of rat duodenum was not increased by either of the stimulants, when the concentrations used were sufficert to induce a maximal contraction. Therefore, two kinds of smooth muscle were used in this study. Male Wistar rats woighing $250-350 \mathrm{~g}$ were killed by a blow on the neck and the duodenum was isolated. The longitudinal muscle was dissected free from the circular muscle and mucosa. Male guinea pigs weighing $350-400 \mathrm{~g}$ were also killed by a blow on the neck and taenia was isolated from the caecum.

Guanylate cyclase preparations were obtained by a modification of the method of Kimura and Murad (4). The muscle was homogenized with a glass-Teflon homogenizer in 9 volumes of $10 \mathrm{mM}$ Tris $(\mathrm{pH} 7.4$ at $4^{\circ} \mathrm{C}$ ) containing $0.3 \mathrm{M}$ mannitol and $0.2 \mathrm{mM}$ EDTA-2Na. The homogenate was centrifuged at $100,000 \times \mathrm{g}$ for $60 \mathrm{~min}$. The pellet (a microsomal fraction) and supernatant were used as guanylate cyclase preparations. All the procedures were performed at $0^{\circ} \mathrm{C}$. Guanylate cyclase activity in the supernatant also was assayed by a modification of the method of Kimura and Murad (4). Reactions were initiated by adding $330-660 \mathrm{hg} / \mathrm{ml}$ of protein in the medium which consisted of $50 \mathrm{mM}$ PIPES (pH 7.0 at $\left.37^{\circ} \mathrm{C}\right), 0.2 \mathrm{mM}$ GTP, $0.5 \mathrm{mM} \mathrm{MgCl}_{2}, 10 \mathrm{mM}$ creatine phosphate, $1 \mathrm{mM}$ dithiothreitol, $1.5 \mathrm{mM}$ MIX, $200 \mu \mathrm{g} / \mathrm{ml}$ creatine kinase and $2 \mathrm{mM}$ GEDTA plus various concentrations of $\mathrm{CaCl}_{2}$ (Ca-buffer). The reactions were allowed to proceed for $4 \mathrm{~min}$ at $37^{\circ} \mathrm{C}$. Five volumes of $50 \mathrm{mM}$ acetate buffer $(\mathrm{pH} 4)$ were added to 
the medium. After exposing the preparation to $95^{\circ} \mathrm{C}$ for $3 \mathrm{~min}$ the mixture was centrifuged at $1,300 \times \mathrm{g}$ for $15 \mathrm{~min}$ and the supernatant was used for estimation of cyclic GMP. Guanylate cyclase activity in the microsomal fraction was then assayed. The reaction medium contained $1 \mathrm{mg} \mathrm{MgCl}_{2}$ and $2 \mathrm{mg} \mathrm{CaCl}_{2}$ according to an ion composition of physiological solution used to assess the mechanical activities of the tissues, because $\mathrm{Ca}$ and $\mathrm{Mg}$ ions play an important role in an interaction of acetylcholine with the receptors (5). Reactions were initiated by adding $67-80 \mu \mathrm{g} / \mathrm{ml}$ of protein to the medium which consisted of $50 \mathrm{mM}$ PIPES. $0.2 \mathrm{mM} \mathrm{GTP,} 4 \mathrm{mM} \mathrm{MnCl}, 1 \mathrm{mM} \mathrm{MgCl}$. $2 \mathrm{mM} \mathrm{CaCl}_{2}, 10 \mathrm{mM}$ creatine phosphate. $1 \mathrm{mM}$ dithiothreitol, $1.5 \mathrm{mM}$ MIX and $200 \mathrm{~kg} / \mathrm{ml}$ creatine kinase. Other procedures were the same as those mentioned in the experiments with the supernatant. The amounts of cyclic GMP formed were estimated by the radioimmunoassay method of Steiner et al. (6). The concentrations of $\mathrm{Ca}^{2+}$ were adjusted by varying the ratio of total $\mathrm{Ca}$ and GEDTA and were calculated as described by Ogawa (7). Protein was assayed by the method of Lowry et al. (8). using bovine serum albumin as a standard. Significance was determined by means of Student's $t$-test for paired values.

Compounds used: PIPES (piperazine$N$ N'-bis(2-ethanesulfonic acid), Wako). EDTA-2Na (ethylenediamine-N,N'-tetraacetate sodium, Wako), GEDTA (glycol- etherdiamine tetraacetic acid. Wako), GTP (guanosine-5' -triphosphate, Boehringer Mannheim). dithiothreitol (BoehringerMannheim), Tris (tris-(hydroxymethyl) aminomethane, Sigma), 8-3H-cyclic GMP $(15 \mathrm{Ci} / \mathrm{mmole}$, Radiochemical Centre). Mix (3-isobutyl-1-methylxanthine, Sigma) and acetylcholine chloride (Dai-ichi).

The microsomal fractions were treated by acetylcholine in concentrations of $10^{-6}$ and $10^{-5} \mathrm{M}$, which were sufficient concentrations to produce the maximal concentration of the guinea pig taenia caecum and longitudinal muscle of rat duodenum.

Acetylcholine $\left(10^{-6}\right.$ and $\left.10^{-5} \mathrm{M}\right)$ did not influence the guanylate cyclase activity in the microsomal fractions derived from the guinea pig taenia caecum and longitudinal muscle of rat duodenum (Table 1). These results suggest that the increase in the tissue level of cyclic GMP in the muscle contracted by the smooth muscle stimulant is not mediated directly through the drug-recepor interaction.

Figure 1 shows the effects of $\mathrm{Ca}^{2+}$ concentrations on guanylate cyclase activity in the supernatant obtained from the both smooth muscles. Guanylate cyclase activity in the supernatant obtained from the guinea pig taenia caecum was higher than that in the longitudinal muscle of rat duodenum (Fig. 1). The activity of the soluble guanylate cyclase obtained from the guinea pig taenia caecum was significantly enhanced by $\mathrm{Ca}^{2+}$ in concentrations over $10^{-6} \mathrm{M}$. while $\mathrm{Ca}^{2+}$ in all

Table 1. Effects of acetylcholine on membrane-bound guanylate cyclase preparations

\begin{tabular}{lcc}
\hline & $\begin{array}{c}\text { Guinea pig taenia caecum } \\
\text { Control }\end{array}$ & $\begin{array}{l}\text { Longitudinal muscle } \\
\text { of rat duodenum }\end{array}$ \\
$10^{-6} \mathrm{M} \mathrm{ACh}$ & $410.6 \pm 23.5$ & $160.5 \pm 14.6$ \\
$10^{-5} \mathrm{M} \mathrm{ACh}$ & $423.8 \pm 18.9$ & $167.2 \pm 9.5$ \\
\hline
\end{tabular}

Values (pmoles cyclic GMP formed $/ \mathrm{min} / \mathrm{mg}$ protein) are presented as means \pm S.E. of 4 experiments. The values in the presence of acetylcholine were not significantly different from the corrosponding control values at $P<0.05$. 

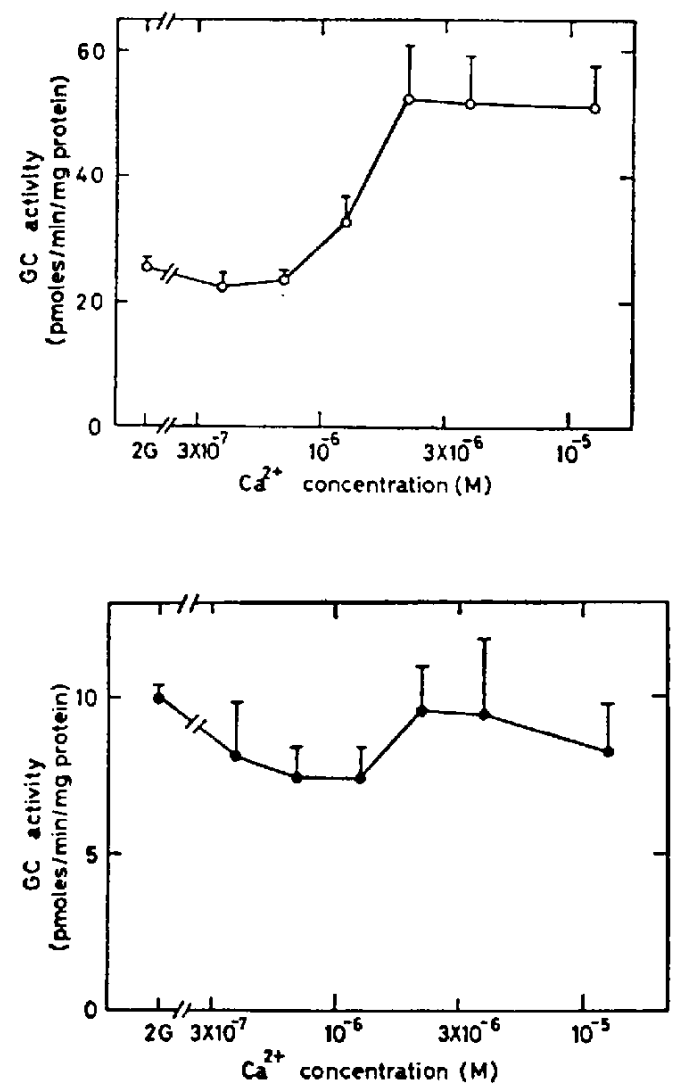

Fig. 1. Effects of $\mathrm{Ca}^{2+}$ concentrations on soluble guanylate cyclase preaparations. Upper: from the guinea pig taenia caecum, lower: from the longitudinal muscle of rat duodenum. Ordinate: guanylate cyclase (GC) activity (pmoles/mg protein), abscissa: $\mathrm{Ca}^{2+}$ concentration (M). $2 \mathrm{G}$ : in the presence of $2 \mathrm{mM}$ GEDTA. Values are presented as means with S.E. of 4 experiments. The values estimated in the preparation from the guinea pig in the higher concentrations (more than $10^{-6} \mathrm{M}$ ) of $\mathrm{Ca}^{2+}$ were significantly different from the value in the presence of $2 \mathrm{mM}$ GEDTA (2G) at $P<0.05$.

the concentrations used did not influence the activity of the soluble guanylate cyclase of the longitudinal muscle of rat duodenum.

Removal of external $\mathrm{Ca}^{2+}$ prevents the increase in cyclic GMP level produced by the smooth muscle stimulants, suggesting that the interactions of the stimulants with their receptors secondarily increase cyclic GMP formation after increasing the intra- cellular $\mathrm{Ca}^{2+}$ concentrations (2). The microsomal fraction used in the present work contained the plasma membrane and sarcoplasmic reticulum (9). The fact that application of acetylcholine to the microsomal fractions did not activate guanylate cyclase suggest that the increase of the tissue level of cyclic GMP in the smooth muscle contracted by the stimulants is not mediated directly through the drug receptor but rather is due to a secondary reaction, after the contraction of smooth muscle. Since activation of gunylate cyclase in the supernatant derived from the guinea pig taenia caecum was activated by concentrations over $10^{-6}$ of $\mathrm{Ca}^{2+}$, which is the intracellular concentrations required to produce contraction of smooth muscle (10), the increase of cyclic GMP brought about in the guinea pig taenia caecum by the stimulant is considered to be due to activation of guanylate cyclase following the increase of intracellular $\mathrm{Ca}^{2+}$ concentration. The soluble guanylate cyclase in the longitudinal muscle of rat duodenum was not activated by the concentrations up to $3 \times 10^{-5} \mathrm{M}$ of $\mathrm{Ca}^{+2}$. These observations suggest that the tissue level of cyclic GMP in the longitudinal muscle of rat duodenum was not increased by the smooth muscle stimulants (3). Furthermore, a difference in the effects of $\mathrm{Ca}^{2+}$ on two soluble guanylate cyclase preparations suggest that guanylate cyclase in the taenia caecum of guinea pig and that of the longitudinal muscle of rat duodenum have different properties, as already reported by Takayanagi et al. (11).

\section{REFERENCES}

1) Schultz, G., Hardman, J.G. and Hurwitz, L.: Cyclic nucleotides and smooth muscle function. Proc. Sixth International Congress Pharmacol, Edited by Kling, E., Vol. 1, p. 203-211. Pergamon Press, Oxford and New York (1976)

2) Wallach, $K$. and Pastan, l.: Stimulation of membranous guanylate cyclase by concentrations 
of calcium that aro in the physiological ranga. Biochery. biophys. Res. Commun. 72, 859865 (1976)

3) Takayanagi, I., Onkubo, $H$. and Takagi, $K_{\text {: }}$ Drug-induced smooth miscie contraction with no change in the lovel of cyclic GMP. Japan. J. Pinarmacol. 26, 501-504 (1970)

4) Kimura, H. and Murad, F.: Evidenco for two different forms of guanylate cyclase in rat heart. J. biol. Chem. 249, 6910-6916 (1974)

5) Takagi, K., Takayanagi, I. and Liao, C.S.: Tho effects of calcium and magnesium ions on crugreceptor interaction. Europ. J. Pharmacol. 19, 330-342(1972)

6) Steiner, A.L., Parker, C.W. and Kipnis, K.M.: Radio-immunoessay for cyclic nucleotides. J. biol. Crem. 247, 1106-1113(1972)

7) Ogawa, Y.: The appearent binding constant of glycoletherciamine tetraceetic acid fer calcium at neutral pll. J. Biochen., Tokyo 64, 255-257 (1968)

8) Lowry, O.H., Rosebrough, N.J., Farr, A.L. and Randall, R.J.: Protoin moasurement with the
Folin phenol rcagont. J. biol. Chem. 193, 265275 (195i)

9) Takayanagi, I., Hongo, T., Hisayama, T. and Kasuya, Y.: Fffects of acetylctoline and histamine on mechanical activity of rabbit taenia coli. Ca-ircorporation and Ca-release in its microsomal fraction. J. Pharm. Dyn. 2, 212-218 (1979)

10) Endo, M., Kitazawa, T., Yagi, S., lino, M. and Kakuta, Y.: Some properties of chemically skinnod smooth musclo fibers. Excitationcontraction coupling in smooth muscle. Edited by Castcols, R., Godtraind. T. and Rüega. J.C.. p. 199-209, Elsevier, Vorth-Holland (1977)

11) Takayanagi, I., Hisayama, T. and Kasuya, Y.: A differerence in effects of prysiological $\mathrm{Ca}^{2+}$ concontrations on activity of guanylate cyclase oreparations obtained from the taenia caecum of guinea pig and from the longitudinal muscto of rat ducdenum. Europ. J. Pharmacol. 52, $389-394(1978)$ 